\title{
The Effects of Contestability of Control on Korean's Firm Performance
}

\author{
Hung Sik KIM'1, Kyung-Shick $\mathrm{CHO}^{2}$
}

Received: August 01, 2020 Revised: October 05, 2020 Accepted: October 15, 2020

\begin{abstract}
The purpose of this paper is to examine the relationship power distribution among several blockholders (contestability) and firm performance. We use a sample of 646 firms listed in the security markets of Korea from 2005 to 2007 . Using different measures of contestability, we verify advance research literature by examining that, when power dispersion among several blockholders (contestability) increases, firm performance is enhanced. The results show that, when the possibility of a controlling coalition being formed among several blocks increases, the corporate value decreases. We also find that this relationship is even more significant in KOSDAQ. However, the smaller the competition of voting rights among blockholders, the higher the corporate performance in KOSPI. The reason for this seems to be that the two markets are different in terms of ownership and governance. This suggests that the effects of contestability among blockholders on firm performance depend on the type of the stock market. The results of this study expand the existing governance literature by analyzing the relationship between contestability among blockholders and firm performance in emerging markets such as Korea. Our findings contribute to policymakers and investors who are interested in the relationship between contestability of control and firm performance in the Korea stock market.
\end{abstract}

Keyword: Contestability of Control, Firm Performance, Blockholder, Ownership, Governance

JEL Classification Code: G30, G32, G35

\section{Introduction}

Contestability of control is defined as the possibility that non-dominant blockholders will challenge or monitor the largest blockholder's power. Blockholder is defined as shareholders who hold at least $5 \%$ of the stock's ownership in the company (Dlugosz et al., 2006).

Traditionally, there are two views on the discussion of the impact of ownership structures. However, these two views contradict each other. For example, Jensen and Meckling (1976) argue that the vertical dimension of corporate governance is based on diluted ownership structures.

${ }^{1}$ First Author. Professor, College of Management and Economics, Dongguk University Gyeongju Campus, South Korea.

Email:kimhs@dongguk.ac.kr

${ }^{2}$ Corresponding Author. Visiting Professor, College of Management and Economics, Dongguk University Gyeongju Campus, South Korea [Postal Address: 109-1411, 163, Dongbuk-ro, Buk-gu, Daegu, 41519, South Korea] E-mail: ksjoh@dongguk.ac.kr

(C) Copyright: The Author(s)

This is an Open Access article distributed under the terms of the Creative Commons Attribution Non-Commercial License (https://creativecommons.org/licenses/by-nc/4.0/) which permits unrestricted non-commercial use, distribution, and reproduction in any medium, provided the original work is properly cited.
Meanwhile, La Porta et al. (1999) show that concentrated corporate ownership is present worldwide (Holderness, 2009). Recently, the debate has focused on the impact of complex ownership involving several blockholders (Gutiérrez \& Pombo, 2009; Konijn et al., 2011). In such ownership structures, the idea of contestability of control arises, this being the motivation among the second largest, non-related blockholders to form coalitions to challenge on monitor dominant blockholder power (Huyghebaert \& Wang, 2012; Maury \& Pajuste, 2005).

Prior literature has shown that contesting the controlling owner by multiple large blockholders proves relevant for many different corporate finance issues such as firm value/performance (Bennedsen \& Wolfenzon, 2000; Bloch \& Hege, 2003; La-Porta et al., 2002; Maury \& Pajuste, 2005; Villalonga \& Amit, 2010; Zwiebel, 1995). This study focuses on the relationship between the contestability of control and firm performance in Korea stock markets.

The prior study on the effect of contestability of control on corporate performance has been based on two opposing views (Maury \& Pajuste, 2005). One shows that there is a positive relationship between contestability of control and firm performance (Jensen \& Meckling, 1976), while the 
other shows that there is negative relationship contestability of control and firm performance (Holderness, 2009; La Porta et al., 1999). The Korean corporate governance (ownership) structure may be different from that of developed countries. For example, the largest blockholder in US companies is mostly institutional investors (Volkova, 2018), while the largest blockholder in Korea is mostly a family including affiliated or affiliated persons and affiliated companies.

Some advance research on the impact of multiple major shareholders performed in a single country framework like China, France, Finland, and Spain (Ben-Nasr et al., 2015; Maury \& Pajuste, 2005; Ruiz-Mallorquí \& Santana Martín, 2011). Some studies have an international scope (Attig et al., 2009; Boubakri \& Ghouma, 2010). However, the question regarding the effect of the institutional environment still demands further research.

The Korean securities market includes the Korea Composite Stock Price Index (KOSPI) and the Korean Securities Dealers Automated Quotations (KOSDAQ). KOSPI is the index of all stocks traded on the Stock Market Partition. It is the typical stock market index of Korea, like the S\&P 500 in the U.S. KOSDAQ is also a trading board of KRX (Korea Stock Exchange) established in 1996. KOSDAQ is benchmarked from the American Exchange, NASDAQ. KOSDAQ is an electronic stock market (NASDAQ). Therefore, KOSPI and KOSDAQ are different in terms of listing conditions, ownership/governance structure, and R\&D.

Our objective is to analyze the effect of contestability of control on firm performance in the Korea stock exchange. We have two contributions to literature and empirical results. First, we emphasize the specific corporate ownership facing family-owned Korean firms when compared to the largest blockholder of an institutional investor in developing countries. Second, we examine a Korea sample, which allows classifying two markets that are different from each other in KOSPI and KOSDAQ. There has been no prior study on the impact of contestability of control on firm performance by separating the two markets.

\section{Prior Literature and Hypotheses}

The concentration of ownership relieves the agency problems through direct manager supervision. However, excessive concentration of ownership in the hands of minority shareholders can deepen the differences of interest between the controlling and minority shareholders. For example, Ang et al. (2000) find that agency costs are considerably higher when outsiders rather than insiders manage the firm, converse relationship to the manager's ownership, rise with the number of non-manager stockholders, and decrease with greater monitoring by banks. Guthrie and Sokolowsky (2010) show that strengthening stockholder power to moderate the conflict between management and shareholders can also have the consequence of aggravating the conflict between future and current shareholders.

Some recent literature has highlighted the benefits of balanced corporate control where some major shareholders are concerned. For example, Mishra (2011) show that the presence of a dominant stockholder is related to a reduction in firm risk-taking (CRT), while the presence and voting rights of the multiple large stockholders (MLS) are closely related to a higher CRT. He also shows that the impact of MLS on CRT is positive in family dominated firms. Nagar et al. (2011) find that shared-ownership corporations report substantially larger ROA and lower cost-to-sales ratios. Santos et al. (2015) find that the existence of a second and third blockholder has a positive effect on firm value. In particular, both the relative strength to other major shareholders and their inducement to monitor the first shareholders plays an important role in the process of corporate governance.

Several major shareholders interact with each other and with the dominant shareholder, creating a specific dynamic within the company. In this ownership structure, when the largest shareholders are out of control of the company, two types of relations can emerge among shareholders. One, the collusion argument stresses the fact that the controlling shareholder can confiscate with other major shareholders, seeking wealth expropriation and diversion of corporate resources for private benefits at the expense of minority shareholders, with the subsequent corporation value destruction (Edmans, 2014). On the other hand, monitoring activity arguments rely on the other major stockholders' incentives to form coalitions or act alone to engage in firm governance activities - such as the threat of "exit" and the "voice", or challenging the power of the controlling stockholder - which may potentially increase firm value (Adjaoud \& Ben-Amar, 2010).

There is a positive relationship between contesting control and firm value. This view argues that multiple large shareholder coalitions with large equity stakes result in stronger and more cohesive ownership, which enhances firm value (Bennedsen \& Wolfenzon, 2000). The empirical literature supports the positive effects of contesting control on firm performance. Maury and Pajuste (2005) report that equal distribution of votes among large blocks of Finnish firms has a positive impact on corporate value. Similarly, Attig et al. (2008) show evidence for a sample of Asian and European firms that contesting control decreases financing costs, which eventually increases corporate value. 
Subsequently, Attig et al. (2009) examine ownership with multiple large stockholders and the effect on corporate value for Asian firms. Their findings indicate that the existence, size, and a number of such major shareholders simplify the premium of corporate value. More recently, Pombo and Taborda (2017) also find that contestability proves to be a critical factor in explaining the value of Latin American firms. Gutiérrez and Pombo (2009) report that equal distribution of stock among large block has a positive effect on corporate value. Similarly, Pombo and Taborda (2017) investigate the impact of power distribution in firms from six Latin American countries and show that the type and existence of a second block within firms with multiple block structures proves to be an important factor in explaining the impact on corporate value. Assuming the impact of contestability on corporate value, we propose the following hypothesis:

H1: Firm performance increases with higher power contestability.

Korea Exchange (KRX) is the sole stock exchange operator in Korea. KRX has some markets division: KOSPI, KOSDAQ, and Derivatives. The differences between KOSPI and KOSDAQ are as follows. First, the KOSPI market, which is a benchmark stock market of Korea, has listed big firms since its opening back in 1956. Its market capitalization amounts to KRW (South Korean Won) 115 billion on the back of strong growth in major big firms. Also, the market was acknowledged to be appropriate for investment by the security markets of major developed countries. This indicates that firms listed on the KOSPI would have an advantage in financing or foreign markets and alliance with overseas firms. The KOSDAQ market began in July 1996 to provide funds for venture firms as well as SMEs in such as IT, BT, and CT. The KOSDAQ has grown noticeably since it was established. The market earned strong recognition as the most liquid emerging market in the world, and this led to the listing of promising global companies on the KOSDAQ market. In other words, it is regarded as a high-quality market in the world. Particularly, KOSDAQ is a market operated by the leading sectors such as IT and BT as well as entertainment, game, and software, etc. Second, the listing policy of the KOSDAQ market is various taking into account the characteristics of the market centered on tech stocks. The listing requirements for the KOSDAQ market are more relaxed when compared to those for the KOSPI market. Specifically, during the listing review, the growth potential of companies is considered, qualitative review items have been simplified and reduced, and exceptional listing requirements taking into account the characteristics of technology growth companies (start-up companies) are also applied. As there appears to be a clear difference between the two markets in terms of ownership structure/governance and listing conditions, we propose the following hypothesis:

H2: The impact of the contestability of power on firm performance will differ between KOSPI and KOSDAQ.

\section{Data Sources and Variables}

Our data set is composed of firm-level information from TS-2000 (provided by the Korea Listed Companies Association) and KIS VALUE Library (provided by Korea Investors Service, Inc.). Our final sample is composed of 8,374 firm-year observations from 646 non-financial firms from Korea exchange between January 1, 2005, and December 31, 2017.

Table 1 shows the definitions of all the variables used in the analysis.

Table 1: Definition of variables

\begin{tabular}{|c|c|c|}
\hline Variables & Variable Name & Definition \\
\hline Q & Tobin's q & $\begin{array}{l}\text { (Equity market value }+ \text { debt } \\
\text { book value)/ Total assets }\end{array}$ \\
\hline MTB & $\begin{array}{l}\text { Market-to-book } \\
\text { ratio }\end{array}$ & $\begin{array}{l}\text { Firm's market capitalization } \\
\text { over book value of } \\
\text { shareholder equity }\end{array}$ \\
\hline SV & Sharply Value & $\begin{array}{l}\text { the probability for the } \\
\text { largest blockholder to form } \\
\text { a coalition with either of the } \\
\text { next two largest blockholders }\end{array}$ \\
\hline $\mathrm{HHIC}$ & $\begin{array}{l}\text { Not contesting } \\
\text { the power of } \\
\text { the largest } \\
\text { blockholder }\end{array}$ & $\begin{array}{l}\sum_{i=1}^{4} S_{i}^{2} \\
S_{i}^{2} \text { is the share of ith } \\
\text { blockholder's shares }\end{array}$ \\
\hline HHID & $\begin{array}{l}\text { Not contesting } \\
\text { the power of } \\
\text { the largest } \\
\text { blockholder }\end{array}$ & $\begin{array}{l}\sum_{i=1}^{4}\left(S_{i}^{2}-S_{-i}^{2}\right) \\
S_{-i}^{2} \text { is the blockholder } \\
\text { different from } i .\end{array}$ \\
\hline SIZE & Firm Size & $\begin{array}{l}\text { Ln of total assets(1 billion } \\
\text { Korean won) }\end{array}$ \\
\hline LEV & Leverage & Debt/Equity \\
\hline DDI & $\begin{array}{l}\text { Dividend pay- } \\
\text { out dummy }\end{array}$ & $\begin{array}{l}1 \text { if the company pays } \\
\text { dividends, and zero } \\
\text { otherwise }\end{array}$ \\
\hline SG & Sales growth & $\begin{array}{l}\text { the percent growth in the net } \\
\text { sales of a business from one } \\
\text { fiscal period to another }\end{array}$ \\
\hline
\end{tabular}


Following prior studies (Demsetz \& Villalonga, 2001; Gompers et al., 2003), our dependent variable is Tobin's Q. We estimate Tobin's Q as the market value of equity plus total debt over total assets. This variable allows our results to be compared with previous research and is widely used in the literature. We also use the market-to-book ratio (MTB) (Jara et al., 2019). This study measure MTB as a corporation's market capitalization over book value of net worth. The main independent variable is contestability of control, which is an index applying the power of the other major blockholders who are not the controlling blockholder. Three measures for blockholder contestability are used: i) the Shapley value of the top three blockholders; ii) two dispersion estimates of the top four blockholders (Jara et al., 2019; Pombo \& Taborda, 2017). The Shapley value, as a resolution to a cooperative game, estimates the possibility for the largest blockholder to shape an alliance with either of the next two largest blockholders. This study calculates the Shapley value according to the method used in Leech (2002). Leech (2002) shows that the construction of oceanic games to calculate power indices is followed. If the largest blockholder's ownership is $20 \%$ and the second and third largest blockholders' ownership is $15 \%$ and $10 \%$, respectively, the Sharply value of the largest blockholder is $23.4 \%$. If the largest blockholder's ownership is $50.5 \%$ and both the second and third largest blockholder's ownership are $0 \%$ and $0 \%$, respectively, the Sharply value of the largest blockholder is 1 . The largest estimation of the Shapley value is 1 . If the Shapley value is close to 1 , the smaller the voting rights conflict between major blockholders, while the closer the Shapley value is to 0 , the greater the voting rights conflict between major blockholders.

Alternatively, we use two Herfindahl-Hirschman Index (HHI) as measures of not contesting the largest blockholder's power. First, the standard HHI Concentration(HHIC) is constructed using the first to fourth-largest blockholders. The second dispersion estimate emphasizes the difference between subsequent blockholders to measure their dispersion. The HHI Difference (HHID) is a measure of shareholder dispersion. The higher the index, the larger the distance between blockholders. In conceptual terms, the HHID reflects the inequality in ownership structure likewise that a Gini coefficient would in the distribution of income. Consequently, the higher this index, the lower the capacity of the second largest blockholders to contest or monitor the largest blockholder.

Additionally, we employ some control variables to prevent problems under specification and to improve the compatibility of our analysis with advanced literature (Attig et al., 2008; Gutiérrez \& Pombo, 2009; Pombo \&
Taborda, 2017; Kim \& Cho,2020; Nguyen et al., 2020; Yim, 2020). SIZE is measured as ln (the firm's total assets). $L E V E$ measures financial leverage (total debt over equity). $D \_D I$ is a dummy that equals (1) if the corporation pays out dividends, and (0) otherwise. SAGR measures the percent growth in the net sales of a business from one fiscal period to another.

\section{Methodology}

The analysis is split up into two stages. First, this study runs a descriptive analysis to estimate how the major characteristics of the sample and the basic relations among the contestability and firm performance. Second, we test our hypotheses through system GMM. To confirm the consistency of our results, this study runs the same models with total samples and KOSPI /KOSDAQ in Korea stock exchange.

The basic analysis model is founded on Eq. (1), in which firm performance depends on contestability and the control variables:

$$
P_{i, t}=\beta_{1} \text { Contestability }_{i, t}+\text { Controls }_{i, t}+i_{i}+u_{i, t}
$$

Where $P_{i, t}$ is the performance of firm $i$ and in period $t$ (e.g. Q and MTB). Contestability ${ }_{i t}$ is the contestability variables(e.g. Sharply value, HHIC, and HHID) and Controls $s_{i, t}$ is the control variables (e.g. Size, Leverage, Dividend Dummy, and Sales Growth).

Our database combines cross-sectional and time-series data, allowing the formation of panel data. Therefore, our empirical analysis is based on unbalanced panel data estimations. There are two main interests when dealing with panel data: the problems of endogeneity and unobservable heterogeneity. Thus, we use System Generalized Method of Moments (GMM), which is an extension of the model suggested by Arellano and Bond (1991). System GMM is a commonly used method to measure the parameters in panel data with unobserved individual-specific heterogeneity and endogenous regressors. Dynamic panel estimation uses first differences to reduce omitted variable bias and unobserved heterogeneity, and make plausibly exogenous instruments founded on lagged values to decrease potential biases from reverse causality and simultaneity. Also, GMM models include lags of the subordination variable as independent variables to better control for past effects and temporal dependency. By investigating our hypotheses with a system GMM estimation approach, we attempting to reduce problems stemming from reverse causality, unobserved firm effects, and simultaneity. The system GMM models in this paper were embodied in Stata (using xtdpdsys). 


\section{Results}

\subsection{Descriptive and Correlation analysis}

Table 2 reports the mean and standard deviation for each variable. The average Tobin's Q and MTB are above one (1.136, 1.264, respectively). On average, the contestability of control shows that the high level of ownership concentration, showing that for every stock in the possessions of the controller, there is $0.669(66.9 \%)$ make shares in the hands of the second, the third, and the fourth blockholders. This is similar to the study result (70.3\%) of Pombo and Taborda (2017) who analyze South American firms. The HHIC and HHID variables (dispersion) give the same information. HHIC's average is $20.5 \%$, while HHID's average is $19.8 \%$. This is a slightly lower value compared to the results of Jara et al. (2019) and Pombo and Taborda (2017) who analyze in South America firms. Jara et al. (2019) show that the average of HHIC and HHID is $29.2 \%, 28.6 \%$, respectively and Pombo and Taborda (2017) also show that the average of HHIC and HHID is $34.8 \%, 23.4 \%$, respectively. This means that the dispersion of Korean major blockholders is slightly lower than that of South America. On average, the leverage of our sample is $106.7 \%$. Most of the corporations in the sample do distribute dividends (payout ratio of about $63.4 \%$ ). The average sales growth of our ample is $7.3 \%$. We analyze the average difference between the two groups by dividing the entire sample into KOSPI and KOSDAQ. Excepting for SV and HHID, the remaining variables show that the difference between the two groups is statistically significant.
Table 3 shows the correlation matrix among the variables. Panels A, B, and C show the correlation in the total sample, KOSPI, and KOSDAQ, respectively. As can be seen, there are significantly high and positively correlated between firm performance (Q and MTB) and among the contestability variables (SV, HHIC, and HHID). We analyze the firm performance and the contestability variables alternately. Therefore, there is no concern about multicollinearity. The correlations between the variables are mixed. The absolute value of the correlation coefficient does not exceed 0.5 , excepting the firm performance and the contestability variables. Despite this correlation among these variables, variance inflation factor (VIF) tests (not tabulated) do not show any problems of multicollinearity in the regression outputs.

\subsection{Analysis Results}

Table 4 shows the results of the baseline model using GMM. The six alternative regressions are grouped based on the two dependent variables (Q and MTB).

First, as expected, the effects of the contestability variable (sharply value) on firm performance is negative and significant at the $1 \%$ level across columns 1 and 4 of Table 4 using Tobin's Q and MTB, respectively, as the dependent variable $(Z=-2.64,-3.88, p<0.1)$. This result agrees with the results analyzed by Maury and Pajuste (2005) for Finnish firms, of a -0.20 regression coefficient, and by Pombo and Taborda (2017) who report regression coefficients of -0.15 for 550 non-financial firms from six Latin American. That is, as the possibility of a controlling coalition being formed between the major blockholder and subsequent blockholders increases, corporate value decreases.

Table 2: Descriptive Statistics and t-test

\begin{tabular}{|l|c|c|c|c|c|c|c|c|}
\hline \multirow{2}{*}{ Variables } & \multicolumn{2}{|c|}{ Total } & \multicolumn{2}{c|}{ KOSPI(a) } & \multicolumn{2}{c|}{ KOSDAQ(b) } & $\begin{array}{c}\text { (a-b) } \\
\text { difference }\end{array}$ \\
\cline { 2 - 8 } & Mean & Std. Dev. & Mean & Std. Dev. & Mean & Std. Dev. & (sig.) \\
\hline Q & 1.136 & 0.771 & 1.066 & 0.666 & 1.237 & 0.891 & -0.172 & $-10.082^{* *}$ \\
\hline MTB & 1.264 & 1.518 & 1.139 & 1.316 & 1.444 & 1.751 & -0.305 & $-9.084^{* *}$ \\
\hline SV & 0.669 & 0.292 & 0.671 & 0.289 & 0.667 & 0.296 & 0.004 & 0.558 \\
\hline HHIC & 0.205 & 0.140 & 0.208 & 0.140 & 0.201 & 0.140 & 0.007 & $2.189^{*}$ \\
\hline HHID & 0.198 & 0.142 & 0.199 & 0.142 & 0.196 & 0.141 & 0.003 & 0.852 \\
\hline SIZE & 12.311 & 1.471 & 12.901 & 1.524 & 11.468 & 0.855 & 1.433 & $49.945^{* *}$ \\
\hline LEV & 1.067 & 2.981 & 1.168 & 3.723 & 0.922 & 1.318 & 0.246 & $3.722^{* *}$ \\
\hline DDI & 0.634 & 0.482 & 0.689 & 0.463 & 0.556 & 0.497 & 0.134 & $12.609^{* *}$ \\
\hline SG & 0.073 & 0.364 & 0.059 & 0.335 & 0.094 & 0.403 & -0.035 & $-4.325^{* *}$ \\
\hline
\end{tabular}

Note: Q is Tobin's q, MTB is Market-to-book ratio, SV is Sharply value, HHIC is Herfindahl-Hirschman Index Concentration, HHID is Herfindahl-Hirschman Index difference, SIZE is LN (total assets, 1 billion south Korean won), LEV is leverage, DDI is dividend pay-out dummy, SG is sales growth. ${ }^{* *} p<0.01,{ }^{*} p<0.05$. 
Table 3: Correlation matrix

\begin{tabular}{|c|c|c|c|c|c|c|c|c|c|}
\hline & $\mathbf{Q}$ & MTB & SV & HHIC & HHID & SIZE & LEV & DDI & SG \\
\hline \multicolumn{10}{|c|}{ Panel A: total } \\
\hline$Q$ & 1 & & & & & & & & \\
\hline MTB & $0.847^{* *}$ & 1 & & & & & & & \\
\hline SV & $-0.177^{* *}$ & $-0.164^{* *}$ & 1 & & & & & & \\
\hline $\mathrm{HHIC}$ & $-0.136^{* *}$ & $-0.118^{* *}$ & $0.851^{* *}$ & 1 & & & & & \\
\hline HHID & $-0.134^{* *}$ & $-0.118^{\star *}$ & $0.861^{* *}$ & $0.995^{\star *}$ & 1 & & & & \\
\hline SIZE & -0.028 & $-0.030^{* *}$ & $-0.061^{* *}$ & $-0.038^{* *}$ & $-0.055^{* *}$ & 1 & & & \\
\hline LEV & -0.008 & $0.268^{* *}$ & -0.026 & -0.013 & -0.016 & $0.076^{* *}$ & 1 & & \\
\hline DDI & $-0.051^{* *}$ & $-0.072^{* *}$ & $0.187^{* *}$ & $0.155^{\star *}$ & $0.147^{* *}$ & $0.199^{* *}$ & $-0.134^{* *}$ & 1 & \\
\hline SG & $0.114^{* *}$ & $0.092^{* *}$ & 0.018 & $0.024^{*}$ & $0.023^{*}$ & -0.009 & -0.013 & $0.069^{* *}$ & 1 \\
\hline \multicolumn{10}{|c|}{ Panel B: KOSPI } \\
\hline Q & 1 & & & & & & & & \\
\hline MTB & $0.809^{* *}$ & 1 & & & & & & & \\
\hline SV & $-0.142^{* *}$ & $-0.123^{* *}$ & 1 & & & & & & \\
\hline $\mathrm{HHIC}$ & $-0.092^{\star *}$ & $-0.071^{* *}$ & $0.843^{\star *}$ & 1 & & & & & \\
\hline HHID & $-0.094^{\star *}$ & $-0.074^{* *}$ & $0.854^{* *}$ & $0.994^{* *}$ & 1 & & & & \\
\hline SIZE & $0.098^{* *}$ & $0.082^{* *}$ & $-0.143^{* *}$ & $-0.106^{\star *}$ & $-0.118^{* *}$ & 1 & & & \\
\hline LEV & -0.001 & $0.336^{* *}$ & $-0.034^{*}$ & -0.027 & $-0.029^{*}$ & $0.060^{* *}$ & 1 & & \\
\hline DDI & 0.019 & 0.006 & $0.114^{* *}$ & $0.087^{* *}$ & $0.084^{\star *}$ & $0.156^{\star *}$ & $-0.153^{\star \star}$ & 1 & \\
\hline SG & $0.124^{\star *}$ & $0.094^{* *}$ & 0.022 & $0.032^{*}$ & $0.030^{*}$ & 0.017 & -0.017 & $0.088^{* *}$ & 1 \\
\hline \multicolumn{10}{|c|}{ Panel C: KOSDAQ } \\
\hline Q & 1 & & & & & & & & \\
\hline MTB & $0.874^{* *}$ & 1 & & & & & & & \\
\hline SV & $-0.218^{* *}$ & $-0.208^{\star *}$ & 1 & & & & & & \\
\hline $\mathrm{HHIC}$ & $-0.181^{* *}$ & $-0.167^{* *}$ & $0.861^{* *}$ & 1 & & & & & \\
\hline HHID & $-0.180^{* *}$ & $-0.165^{\star \star}$ & $0.869^{* *}$ & $0.996^{* *}$ & 1 & & & & \\
\hline SIZE & $-0.097^{* *}$ & $-0.095^{\star *}$ & $0.094^{* *}$ & $0.066^{* *}$ & $0.055^{\star *}$ & 1 & & & \\
\hline LEV & -0.010 & $0.271^{* *}$ & -0.009 & $0.033^{*}$ & 0.030 & $0.093^{* *}$ & 1 & & \\
\hline DDI & $-0.092^{* *}$ & $-0.125^{\star *}$ & $0.284^{* *}$ & $0.239^{* *}$ & $0.230^{* *}$ & $0.169^{* *}$ & $-0.167^{* *}$ & 1 & \\
\hline SG & $0.096^{* *}$ & $0.082^{* *}$ & 0.013 & 0.017 & 0.014 & 0.015 & 0.004 & $0.063^{* *}$ & 1 \\
\hline
\end{tabular}

Note: Q is Tobin's q, MTB is Market-to-book ratio, SV is sharply value, HHIC is Herfindahl-Hirschman Index Concentration, HHID is Herfindahl-Hirschman Index difference, SIZE is LN (total assets, 1 billion south Korean won), LEV is leverage, DDI is dividend pay-out dummy, SG is sales growth. ${ }^{* *}$, * indicate significance at $1 \%$ and $5 \%$ levels (both sides), respectively. 
Table 4: Contestability of control and firm performance (1): generalized method of moments

\begin{tabular}{|c|c|c|c|c|c|c|c|}
\hline \multirow{2}{*}{ Variables } & \multirow{2}{*}{\begin{tabular}{|c|} 
Pre- \\
dicted \\
Sign \\
\end{tabular}} & \multicolumn{3}{|c|}{$\mathbf{Q}$} & \multicolumn{3}{|c|}{ MTB } \\
\hline & & (1) & (2) & (3) & (4) & (5) & (6) \\
\hline $\begin{array}{l}\text { Sharply } \\
\text { value }\end{array}$ & $(-)$ & $\begin{array}{c}-0.183^{\star * *} \\
(-2.64)\end{array}$ & & & $\begin{array}{c}-0.452^{* * *} \\
(-3.88)\end{array}$ & & \\
\hline $\mathrm{HHIC}$ & $(-)$ & & $\begin{array}{l}-0.240 \\
(-0.73)\end{array}$ & & & $\begin{array}{c}-0.588^{\star *} \\
(-2.17)\end{array}$ & \\
\hline HHID & $(-)$ & & & $\begin{array}{l}-0.190 \\
(-0.86)\end{array}$ & & & $\begin{array}{c}-0.659^{\star *} \\
(-2.47)\end{array}$ \\
\hline Firm size & $(+)$ & $\begin{array}{c}0.080^{* * *} \\
(22.01)\end{array}$ & $\begin{array}{c}0.074^{\star * *} \\
(25.68)\end{array}$ & $\begin{array}{c}0.073^{\star \star \star} \\
(26.28)\end{array}$ & $\begin{array}{c}0.112^{\star * *} \\
(18.06)\end{array}$ & $\begin{array}{c}0.098^{\star \star *} \\
(21.61)\end{array}$ & $\begin{array}{c}0.098^{\star \star *} \\
(22.67)\end{array}$ \\
\hline Leverage & (?) & $\begin{array}{l}0.001 \\
(0.50)\end{array}$ & $\begin{array}{l}0.001 \\
(0.43)\end{array}$ & $\begin{array}{l}0.001 \\
(0.37)\end{array}$ & $\begin{array}{c}0.191^{* * *} \\
(23.13)\end{array}$ & $\begin{array}{c}0.194^{* * *} \\
(23.90)\end{array}$ & $\begin{array}{c}0.193^{* * *} \\
(23.71)\end{array}$ \\
\hline DDividend & $(+)$ & $\begin{array}{c}0.058^{* * *} \\
(4.70)\end{array}$ & $\begin{array}{c}0.056^{\star * *} \\
(4.55)\end{array}$ & $\begin{array}{c}0.056^{* * *} \\
(4.54)\end{array}$ & $\begin{array}{c}0.109^{* * *} \\
(4.62)\end{array}$ & $\begin{array}{c}0.108^{* * *} \\
(4.58)\end{array}$ & $\begin{array}{c}0.108^{* * *} \\
(4.57)\end{array}$ \\
\hline $\begin{array}{l}\text { Sales } \\
\text { growth }\end{array}$ & $(+)$ & $\begin{array}{l}0.017 \\
(0.74)\end{array}$ & $\begin{array}{l}0.020 \\
(0.86)\end{array}$ & $\begin{array}{l}0.020 \\
(0.85)\end{array}$ & $\begin{array}{c}0.142^{* * *} \\
(3.87)\end{array}$ & $\begin{array}{c}0.148^{\star * *} \\
(3.88)\end{array}$ & $\begin{array}{c}0.146^{* * *} \\
(3.86)\end{array}$ \\
\hline \multicolumn{2}{|c|}{ Observations } & \multicolumn{6}{|c|}{7,722} \\
\hline \multicolumn{2}{|c|}{ No. of firms } & \multicolumn{6}{|c|}{646} \\
\hline \multicolumn{2}{|c|}{ No. of instrument } & \multicolumn{6}{|c|}{82} \\
\hline \multicolumn{2}{|c|}{ Wald chi2(6) } & $7804.8^{* * *}$ & $7283.4^{* * *}$ & $7270.43^{\star \star *}$ & $7561.6^{\star * *}$ & $7442.4^{\star * *}$ & $7479.1^{* * *}$ \\
\hline $\mathrm{AR}(1)$ & & $-2.18^{* *}$ & $-2.17^{* *}$ & $-2.17^{* *}$ & $-2.29^{* *}$ & $-2.27^{* *}$ & $-2.28^{\star *}$ \\
\hline $\mathrm{AR}(2)$ & & 1.29 & 1.29 & 1.28 & -0.77 & -0.84 & -0.83 \\
\hline \multicolumn{2}{|c|}{$\begin{array}{l}\text { Sargan test } \\
\text { chi2(76) }\end{array}$} & $281.2^{\star \star \star}$ & $277.3^{\star \star \star}$ & $277.6^{\star \star \star}$ & $255.6^{\star \star \star}$ & $254.2^{\star \star \star}$ & $255.3^{* * *}$ \\
\hline
\end{tabular}

Note: The system GMM models were embodied in Stata (using xtdpdsys). Z values are in parentheses. Wald Chi2 represents statistics about the fit of the model. AR (1) and AR (2) represent statistics for testing the existence of the first and second time series correlations of the residuals. Sargan test chi represents the statistics for the overidentifying restrictions test through the correlation between instrument variables and error terms. ${ }^{* * *},{ }^{* *},{ }^{*}$ indicate significance at $1 \%, 5 \%$, and $10 \%$ levels (both sides), respectively.

Second, to confirm the average effect of contestability on firm performance, this study employs two further measures of lack of contestability (based on ownership dispersion), HHIC, and HHID, which are used by Herfindahl measures. Inherently, higher Herfindahl measure values indicate dispersed contestability power (e.g. lack of contestability). The regression coefficients are presented in columns 2, 3 , and 5, 6 of Table 3. The regression coefficients are (as expected) negative and significant relationship between the lack of contestability variables and MTB $(Z=-2.17,-2.47$, $\mathrm{p}<0.5$ ), excepting Tobin's $Q$ in 2,3 of Table 3 . These results indicate that the absence of contestability has a negative effect on corporation performance. This result enhances the one derived using the Shapley value. In facts the lower the control power of the second or third blockholder, the greater the rent capture by the controlling blockholder. In summary, these results provide validation of our first hypothesis, which proposed a positive effect on corporation performance because of potential tunneling and rent diversion by the blockholders' controlling coalition in the Korea securities market.

Third, we examine the relationship between control variables and firm performance. There is a significant positive relationship between firm size and company performance at the $1 \%$ level. This means that the larger the company, the higher the firm performance. However, there is positive and statistically significant evidence between leverage and firm performance in 4, 5, and 6 columns of Table 3 using MTB. Companies that pay dividends show high performance. The sales growth rate appears to have a positive effect on corporate performance in 4, 5, and 6 columns of Table 3 using MTB. 
In order to examine the consistency of our results, this study examines Eq. (1) using panel analysis of fixed effect (see Table 5). The results observed across all the columns of Table 5 are approximately similar to those obtained in Table 4, excepting columns (2) and (3).

\subsection{Additional results: KOSPI vs. KOSDAQ}

Table 6 shows additional analysis results using GMM. We divide the Korea stock market into KOSPI and KOSDAQ. This is because the impact of contestability of control on corporate performance seems to be different. We use only Tobin's Q as the dependent variable. The reason to use only Tobin's Q is that it is similar to using MTB as a dependent variable. The analysis results can be summarized as follows.

In the KOSPI market, contrary to expectations, it shows a statistically significant positive relationship between Shapley value and corporate performance $(Z=1.66, p<0.1)$. This means that the higher the Shapley value, the higher the firm performance in KOSPI. The high value of Sharply in a company means that the contestability of control is weak. In other words, the smaller the competition of voting rights among blockholders, the higher the corporate performance. It also shows a statistically significant positive relationship between HHIC / HHID and corporate performance $(Z=4.40$, 4.25, $\mathrm{P}<0.01)$. However, in the KOSDAQ market, the results show across the column (4), (5), and (6) of Table 6 are approximately similar to those obtained the column (1) in Table 4 and all the column (4), (5), and (6) Table 5. The reason for this different result seems that the two groups' different ownership/governance structures, such as KOSPI and KOSDAQ, influence corporate performance. KOSPI is mainly composed of large companies, while KOSDAQ is mainly composed of venture companies and SMEs. KOSPI's market entry requirements (e.g. ownership) have been strengthened, while KOSDAQ's market entry requirements are relatively relaxed. In addition, the two markets differ in age, R\&D, and investment activities.

Table 5: Contestability of control and firm performance: Panel-fixed effect estimates

\begin{tabular}{|c|c|c|c|c|c|c|c|}
\hline \multirow{2}{*}{ Variables } & \multirow{2}{*}{$\begin{array}{c}\text { Pre } \\
\text { dicted } \\
\text { Sign }\end{array}$} & \multicolumn{3}{|c|}{$\mathbf{Q}$} & \multicolumn{3}{|c|}{ MTB } \\
\hline & & (1) & (2) & (3) & (4) & (5) & (6) \\
\hline Sharply value & $(-)$ & $\begin{array}{c}-0.360^{\star * *} \\
(-8.65)\end{array}$ & & & $\begin{array}{c}-0.668^{* * *} \\
(-6.48)\end{array}$ & & \\
\hline $\mathrm{HHIC}$ & $(-)$ & & $\begin{array}{c}-0.343^{\star * *} \\
(-3.15)\end{array}$ & & & $\begin{array}{c}-0.777^{* * *} \\
(-3.51)\end{array}$ & \\
\hline HHID & $(-)$ & & & $\begin{array}{c}-0.364^{* * *} \\
(-3.40)\end{array}$ & & & $\begin{array}{c}-0.835^{* * *} \\
(-3.85)\end{array}$ \\
\hline Firm size & $(+)$ & $\begin{array}{c}-0.047^{\star \star \star} \\
(-4.06)\end{array}$ & $\begin{array}{c}-0.115^{* * *} \\
(-4.94)\end{array}$ & $\begin{array}{c}-0.116^{* * *} \\
(-4.96)\end{array}$ & $\begin{array}{c}-0.318^{* * *} \\
(-6.72)\end{array}$ & $\begin{array}{c}-0.309^{* * *} \\
(-6.51)\end{array}$ & $\begin{array}{c}-0.310^{* * *} \\
(-6.54)\end{array}$ \\
\hline Leverage & (?) & $\begin{array}{l}-0.001 \\
(-0.22)\end{array}$ & $\begin{array}{l}-0.000 \\
(-0.14)\end{array}$ & $\begin{array}{l}-0.000 \\
(-0.31)\end{array}$ & $\begin{array}{c}0.149^{* * *} \\
(31.03)\end{array}$ & $\begin{array}{l}0.149^{* * *} \\
(30.97)\end{array}$ & $\begin{array}{c}0.149^{* * *} \\
(30.98)\end{array}$ \\
\hline DDividend & $(+)$ & $\begin{array}{c}0.066^{* * *} \\
(3.58)\end{array}$ & $\begin{array}{c}0.093^{* * *} \\
(4.78)\end{array}$ & $\begin{array}{c}0.093^{* * *} \\
(4.81)\end{array}$ & $\begin{array}{c}0.198^{* * *} \\
(5.02)\end{array}$ & $\begin{array}{c}0.191^{\star * *} \\
(4.83)\end{array}$ & $\begin{array}{c}0.192^{* * *} \\
(4.86)\end{array}$ \\
\hline Sales growth & $(+)$ & $\begin{array}{c}0.211^{* * *} \\
(11.63)\end{array}$ & $\begin{array}{c}0.202^{* * *} \\
(11.10)\end{array}$ & $\begin{array}{c}0.202^{* * *} \\
(11.10)\end{array}$ & $\begin{array}{c}0.342^{* * *} \\
(9.27)\end{array}$ & $\begin{array}{c}0.340^{* * *} \\
(9.20)\end{array}$ & $\begin{array}{c}0.340^{* * *} \\
(9.21)\end{array}$ \\
\hline \multicolumn{2}{|l|}{ Observations } & \multicolumn{6}{|c|}{8,374} \\
\hline \multicolumn{2}{|l|}{ No. of firms } & \multicolumn{6}{|c|}{646} \\
\hline \multicolumn{2}{|l|}{ Year Effect } & \multicolumn{6}{|c|}{ Yes } \\
\hline \multicolumn{2}{|l|}{ R-square } & 0.07 & 0.07 & 0.07 & 0.15 & 0.15 & 0.15 \\
\hline \multicolumn{2}{|c|}{ Lagrange multi. test } & $7447.0^{* * *}$ & $7660.7^{\star \star \star}$ & $7670.4^{\star \star *}$ & $4749.9^{* \star *}$ & $4912.8^{* \star \star}$ & $4923.4^{* * *}$ \\
\hline \multicolumn{2}{|l|}{ Hausman test } & $356.9^{* * *}$ & $351.3^{* * *}$ & $349.2^{* * *}$ & $140.8^{* * *}$ & $189.0^{* * *}$ & $182.4^{* * *}$ \\
\hline \multicolumn{2}{|l|}{ F-value } & $35.8^{* * *}$ & $34.5^{* * *}$ & $34.6^{* * *}$ & $83.9^{* * *}$ & $81.8^{* * *}$ & $82.0^{* * *}$ \\
\hline
\end{tabular}

Note: $t$ values are in parentheses. ${ }^{* * *}$ indicate significance at $1 \%$ levels (both sides). 
Table 6: Contestability of control and firm performance (2): generalized method of moments

\begin{tabular}{|c|c|c|c|c|c|c|}
\hline \multirow{2}{*}{ Variables } & \multicolumn{3}{|c|}{ KOSPI } & \multicolumn{3}{|c|}{ KOSDAQ } \\
\hline & (1) & (2) & (3) & (4) & (5) & (6) \\
\hline Sharply value & $\begin{array}{l}0.094^{*} \\
(1.66)\end{array}$ & & & $\begin{array}{c}-0.258^{\star * *} \\
(-4.11)\end{array}$ & & \\
\hline $\mathrm{HHIC}$ & & $\begin{array}{c}0.592^{* * *} \\
(4.40)\end{array}$ & & & $\begin{array}{c}-0.781^{* * *} \\
(-4.75)\end{array}$ & \\
\hline HHID & & & $\begin{array}{c}0.553^{* * *} \\
(4.25)\end{array}$ & & & $\begin{array}{c}-0.603^{\star * *} \\
(-3.78)\end{array}$ \\
\hline Firm size & $\begin{array}{l}0.045^{* * *} \\
(15.76)\end{array}$ & $\begin{array}{c}0.041^{* * *} \\
(19.98)\end{array}$ & $\begin{array}{c}0.042^{* * *} \\
(21.82)\end{array}$ & $\begin{array}{l}0.101^{* * *} \\
(32.93)\end{array}$ & $\begin{array}{c}0.099^{* * *} \\
(41.69)\end{array}$ & $\begin{array}{c}0.097^{* \star \star} \\
(41.71)\end{array}$ \\
\hline Leverage & $\begin{array}{l}0.000 \\
(0.00)\end{array}$ & $\begin{array}{l}0.000 \\
(0.11)\end{array}$ & $\begin{array}{l}0.000 \\
(0.08)\end{array}$ & $\begin{array}{l}0.010 \\
(1.31)\end{array}$ & $\begin{array}{l}0.012 \\
(1.61)\end{array}$ & $\begin{array}{l}0.012 \\
(1.61)\end{array}$ \\
\hline DDividend & $\begin{array}{c}0.040^{\star \star *} \\
(3.79)\end{array}$ & $\begin{array}{c}0.039^{\star * *} \\
(3.76)\end{array}$ & $\begin{array}{c}0.039^{* * *} \\
(3.80)\end{array}$ & $\begin{array}{c}0.113^{\star \star \star} \\
(5.76)\end{array}$ & $\begin{array}{c}0.111^{\text {*** }} \\
(5.62)\end{array}$ & $\begin{array}{c}0.111^{* * *} \\
(5.65)\end{array}$ \\
\hline Sales growth & $\begin{array}{c}0.087^{\star * *} \\
(5.00)\end{array}$ & $\begin{array}{c}0.072^{\star \star *} \\
(3.73)\end{array}$ & $\begin{array}{c}0.074^{\star * *} \\
(3.88)\end{array}$ & $\begin{array}{c}0.065^{\star \star \star} \\
(3.23)\end{array}$ & $\begin{array}{c}0.069^{* * *} \\
(4.33)\end{array}$ & $\begin{array}{c}0.068^{\star \star \star} \\
(3.41)\end{array}$ \\
\hline Observations & & 4,543 & & & 3,179 & \\
\hline No. of firms & & 380 & & & 266 & \\
\hline No. of instrument & & & & & & \\
\hline Wald Chi2(6) & $16039.8^{* * *}$ & $13653.2^{* * *}$ & $13966.7^{* * *}$ & $13955.6^{* * *}$ & $14035.9^{* * *}$ & $13892.5^{* * *}$ \\
\hline$A R(1)$ & $-3.04^{* * *}$ & $-3.00^{* * *}$ & $-3.00^{* * *}$ & $-1.66^{*}$ & $-1.65^{\star}$ & $-1.65^{\star}$ \\
\hline$A R(2)$ & 1.23 & 1.22 & 1.22 & 0.41 & 0.42 & 0.42 \\
\hline $\begin{array}{l}\text { Sargan test } \\
\text { chi2(76) }\end{array}$ & $235.9^{* * *}$ & $228.5^{\star * *}$ & $229.0^{* * *}$ & $160.5^{* * *}$ & $160.8^{* * *}$ & $161.8^{* * *}$ \\
\hline
\end{tabular}

Note: The system GMM models were embodied in Stata (using xtdpdsys). Z values are in parentheses. Wald Chi2 represents statistics about the fit of the model. AR (1) and AR (2) represent statistics for testing the existence of the first and second time series correlations of the residuals. Sargan test chi represents the statistics for the over identifying restrictions test through the correlation between instrument variables and error terms. ${ }^{* * *},{ }^{*}$ indicate significance at $1 \%$, and $10 \%$ levels (both sides), respectively.

\section{Conclusions}

We investigate the impact of contestability among major blockholders on corporate value for a sample of nonfinancial listed companies in Korea. Korea provides a good opportunity to analyze the interaction among some major blockholders given the family concentrated ownership. We assume that firm performance increases with higher power contestability and the impact of contestability of power on firm performance will differ between KOSPI and KOSDAQ. Consistent with advance research, our results support that firm performance increases with higher power contestability. We also find that the impact of contestability control on corporate performance is different in KOSPI and KOSDAQ.

The results of this study expand the existing governance literature by analyzing the relationship between contestability among blockholders and firm performance in family concentrated ownership such as Korea. Our findings contribute to investors who are interested in the relationship between contestability of control and firm performance in the Korea stock market. Our results have policy implication for policymakers. Our results suggest that policymakers need to implement differentiated policies in the institutional environment of the stock market.

\section{References}

Adjaoud, F., \& Ben-Amar, W. (2010). Corporate governance and dividend policy: shareholders' protection or expropriation? Journal of Business Finance \& Accounting, 37(5-6), 648-667.

Ang, J. S., Cole, R. A., \& Lin, J. W. (2000). Agency costs and ownership structure. The Journal of Finance, 55(1), 81-106. 
Arellano, M., \& Bond, S. (1991). Some tests of specification for panel data: Monte Carlo evidence and an application to employment equations. The Review of Economic Studies, 58(2), 277-297.

Attig, N., Guedhami, O., \& Mishra, D. (2008). Multiple large shareholders, control contests, and implied cost of equity. Journal of Corporate Finance, 14(5), 721-737.

Attig, N., El Ghoul, S., \& Guedhami, O. (2009). Do multiple large shareholders play a corporate governance role? Evidence from East Asia. Journal of Financial Research, 32(4), 395-422.

Ben-Nasr, H., Boubaker, S., \& Rouatbi, W. (2015). Ownership structure, control contestability, and corporate debt maturity. Journal of Corporate Finance, 35, 265-285.

Bennedsen, M., \& Wolfenzon, D. (2000). The balance of power in closely held corporations. Journal of Financial Economics, 58(1-2), 113-139.

Bloch, F., \& Hege, U. (2003). Multiple shareholders and control contests. Available at SSRN 2273211.

Boubakri, N., \& Ghouma, H. (2010). Control/ownership structure, creditor rights protection, and the cost of debt financing: International evidence. Journal of Banking \& Finance, 34(10), 2481-2499.

Demsetz, H., \& Villalonga, B. (2001). Ownership structure and corporate performance. Journal of Corporate Finance, 7(3), 209-233.

Dlugosz, J., Fahlenbrach, R., Gompers, P., \& Metrick, A. (2006). Large blocks of stock: Prevalence, size, and measurement. Journal of Corporate Finance, 12(3), 594-618.

Edmans, A. (2014). Blockholders and corporate governance. Annual Review of Financial Economics, 6(1), 23-50.

Gompers, P., Ishii, J., \& Metrick, A. (2003). Corporate governance and equity prices. The Quarterly Journal of Economics, 118(1), 107-156.

Guthrie, K., \& Sokolowsky, J. (2010). Large shareholders and the pressure to manage earnings. Journal of Corporate Finance, 16(3), 302-319.

Gutiérrez, L. H., \& Pombo, C. (2009). Corporate ownership and control contestability in emerging markets: The case of Colombia. Journal of Economics and Business, 61(2), 112-139.

Holderness, C. G. (2009). The myth of diffuse ownership in the United States. The Review of Financial Studies, 22(4), 1377-1408.

Huyghebaert, N., \& Wang, L. (2012). Expropriation of minority investors in Chinese listed firms: The role of internal and external corporate governance mechanisms. Corporate Governance: An International Review, 20(3), 308-332.

Jara, M., López-Iturriaga, F., San-Martín, P., \& Saona, P. (2019). Corporate governance in Latin American firms: Contestability of control and firm value. BRQ Business Research Quarterly, $22(4), 257-274$.
Jensen, M. C., \& Meckling, W. H. (1976). Theory of the firm: Managerial behavior, agency costs, and ownership structure. Journal of Financial Economics 3(4), 305-360.

Kim, H. S., \& Cho, K. S. (2020). The Determinants of Blockholder Presence: Evidence from Korea. Journal of Asian Finance, Economics, and Business, 7(4), 29-39. https://doi.org/10.13106/ jafeb.2020.vol7.no4.29

Konijn, S. J., Kräussl, R., \& Lucas, A. (2011). Blockholder dispersion and firm value. Journal of Corporate Finance, 17(5), 1330-1339.

La Porta, R., Lopez-de-Silanes, F., \& Shleifer, A. (1999). Corporate ownership around the world. The Journal of Finance, 54(2), 471-517.

La Porta, R., Lopez-de-Silanes, F., Shleifer, A., \& Vishny, R. (2002). Investor protection and corporate valuation. The Journal of Finance, 57(3), 1147-1170.

Leech, D. (2002). Designing the Voting System for the Council of the European Union. Public Choice, 113(3-4), 437-464.

Maury, B., \& Pajuste, A. (2005). Multiple large shareholders and firm value. Journal of Banking \& Finance, 29(7), 1813-1834.

Mishra, D. R. (2011). Multiple large shareholders and corporate risk taking: Evidence from East Asia. Corporate Governance: An International Review, 19(6), 507-528.

Nagar, V., Petroni, K., \& Wolfenzon, D. (2011). Governance problems in closely held corporations. Journal of Financial and Quantitative Analysis, 943-966.

Nguyen, T. X. H., Pham, T. H., Dao, T. N., Nguyen, T. N., \& Tran, T. K. N. (2020). The Impact of Foreign Ownership and Management on Firm Performance in Vietnam. Journal of Asian Finance, Economics and Business, 7(9), 409-418. https://doi.org/10.13106/ jafeb.2020.vol7.no9.409

Pombo, C., \& Taborda, R. (2017). Stock liquidity and second blockholder as drivers of corporate value: Evidence from Latin America. International Review of Economics \& Finance, 51, 214-234.

Ruiz-Mallorquí, M. V., \& Santana-Martin, D. J. (2011). Dominant institutional owners and firm value. Journal of Banking \& Finance, 35(1), 118-129.

Santos, M. S., Moreira, A. C., \& Vieira, E. S. (2015). Governance with complex structures: Evidence from Western European countries. Journal of Business Economics and Management, 16(3), 542-557.

Villalonga, B., \& Amit, R. (2010). Family control of firms and industries. Financial Management, 39(3), 863-904.

Volkova, E. (2018). Blockholders diversity: Effect of polyphony on the power of monitoring. Available at SSRN 3047469.

Yim, S. G. (2020). Individual blockholder's influence on accounting quality: Evidence from Korea. Journal of Asian Finance, Economics and Business, 7(1), 59-69. https://doi.org/10.13106/ jafeb.2020.vol7.no1.59

Zwiebel, J. (1995). Corporate conservatism and relative compensation. Journal of Political Economy, 103(1), 1-25. 